\title{
Wastewater Containing 1,2-Dihydro-2,2,4-Trimethylquinoleyn Treated by Electrolysis and Respirometric Method
}

\author{
Thelma Helena Inazaki ${ }^{1}$, Peterson Bueno de Moraes $^{2}$, Gisela Regis ${ }^{1}$, Paulo Renato Matos Lopes ${ }^{1}$, Renato Nallin Montagnolli ${ }^{1}$, Antonio
} Carlos Simões Piao $^{3}$ and Ederio Dino Bidoia ${ }^{1 *}$

${ }^{1}$ Department of Biochemistry and Microbiology, IB, UNESP - Univ Estadual Paulista, Rio Claro, Brazil ${ }^{2}$ Department of Technology in Environmental Management - DTSA, FT/UNICAMP, Limeira, Brazil

${ }^{3}$ DEMAC, IGCE, UNESP - Univ Estadual Paulista, Rio Claro, Brazil

\begin{abstract}
The electrolytic treatment of a real industrial effluent and simulated wastewater containing the 1,2-dihydro2,2,4-trimethylquinoleyn compound (Naugard $\mathrm{Q}^{\circledR}$ ) had been investigated in order to improve the wastewater biodegradability. The electrolysis was carried out in a batch electrolytic cell using $70 \mathrm{TiO}_{2} / 30 \mathrm{RuO}{ }_{2}$ electrodes (DSA anode). After electrochemical treatment, wastewaters were evaluated in terms of Naugard ${ }^{\circledR}$ concentration, UV-visible spectrophotometry and biodegradation. Further analyses were conducted in simulated wastewater by gas chromatography and the biodegradation process was monitored using respirometric flasks. Both real effluent and simulated wastewater presented a decrease in Naugard $\mathrm{Q}^{\circledR}$ concentration. The simulated wastewater electrolytic treatment provided concentration reduction of Naugard $\mathrm{Q}^{\circledR}$ about $52.04 \%$ after $60 \mathrm{~min}$, whereas real effluent concentration was reduced by $62.60 \%$ after 40 minutes. Furthermore, UV-visible spectra and gas chromatograms presented significant alterations in molecular structure of the compound. After 30 min electrolysis, an increase in simulated wastewater biodegradation was observed. In real effluent, the biodegradation response was faster, as more $\mathrm{CO}_{2}$ was produced in assays that underwent 10 and 25 minutes of electrolytic treatment. This result is probably related to modifications in Naugard ${ }^{\circledR}{ }^{\circledR}$ molecular structure. It was concluded that the electrolytic treatment followed by bioremediation could be an alternate treatment to degrade this compound.
\end{abstract}

Keywords: Naugard $\mathrm{Q}^{\circledR}$; industrial effluent; DSA electrodes; biodegradation; water treatment

\section{Introduction}

The Naugard $Q^{\circledR}$ compound(1,2-dihydro-2,2,4-trimethylquinoleyn) is an aromatic amine which can be found in toxic effluents from rubber antioxidant and antiozonant chemical industry located in Rio Claro (Sao Paulo, Brazil). This compound was chosen mainly because it is one of the most important persistent compounds present in effluents from Brazilian chemical industries [1]. Moreover, many aromatic amines have been reported to be powerful carcinogens and mutagens [2-3], causing treatment of industrial wastewaters containing these chemicals to become a very important way to minimize environmental threatening.

Biological treatments are considered the most efficient and low cost methods in environmental impact reducing of several industrial effluents containing organic pollutants [4]. However, wastewater containing aromatic compounds is both recalcitrant and toxic towards microorganisms during conventional biological treatment. In this context, electrochemical treatment can be a powerful tool in environmental complex matrixes degradation [5-8].

In electrolytic processes, organic and toxic pollutants are usually destroyed by direct anodic process or by indirect anodic oxidation via oxidants generation such as hydroxyl radical, ozone, etc [9]. The electrochemical technology has attracted a huge deal of attention due to its versatility, amenability to automation and environmental compatibility. In fact, the main reagent is the electron, which is considered a "clean reagent" [10]. Besides, biodegradability of wastewaters can usually be improved after electrolytic treatment. Presently it is recognized that the simple modification of the molecular structure of a compound can reduce dramatically its toxicity and increase its biodegradability [11]. Generally, a persistent molecule has aromatic rings and its oxidation results in more biodegradable or biocompatible molecules.
The purpose of this study was to test $70 \% \mathrm{TiO}_{2} / 30 \% \mathrm{RuO}_{2}$ electrodes in two electrochemical treatments in a batch electrolytic cell: (a) real effluent of a rubber antioxidant and antiozonant chemical industry and (b) simulated wastewater containing the Naugard $Q^{\circledR}$ compound. After electrolysis, wastewater characteristics were monitored such as concentration, biodegradation and analysis of UV-visible spectrophotometry and gas chromatography.

\section{Material and Methods}

\section{Real effluent}

It was used a real effluent from a rubber antioxidant and antiozonant chemical industry located in Rio Claro (Sao Paulo, Brazil). This sample was collected at the industry directly before the biological treatment owing to obtain the raw effluent.

Thereafter, the solution was filtered and stored in amber glass flask at $4^{\circ} \mathrm{C}$ in order to avoid photodegradation. The Naugard $\mathrm{Q}^{\circledR}$ concentration obtained in the real effluent was $14.93 \mathrm{mg} \mathrm{L}^{-1}$ measured by quantitative analysis using UV-visible absorbance.

According to real effluent, concentrations of organic compound

*Corresponding author: Ederio Dino Bidoia, Department of Biochemistry and Microbiology, IB, UNESP - Univ Estadual Paulista, Avenida 24 A, 1515 - Bela Vista; CEP: 13506-900; Rio Claro-SP, Brazil, Tel: (55) 19-35264191; Fax: (55) 1935264176; E-mail: ederio@rc.unesp.br

Received August 24, 2010; Accepted September 28, 2010; Published October 01, 2010

Citation: Inazaki TH, de Moraes PB, Regis G, Matos Lopes PR, Montagnolli RN, et al. (2010) Wastewater Containing 1,2-Dihydro-2,2,4-Trimethylquinoleyn Treated by Electrolysis and Respirometric Method. J Waste Water Treatment Analysis 1:101. doi:10.4172/2157-7587.1000101

Copyright: (c) 2010 Inazaki TH, et al. This is an open-access article distributed under the terms of the Creative Commons Attribution License, which permits unrestricted use, distribution, and reproduction in any medium, provided the original author and source are credited. 
Citation: Inazaki TH, de Moraes PB, Regis G, Matos Lopes PR, Montagnolli RN, et al. (2010) Wastewater Containing 1,2-Dihydro-2,2,4Trimethylquinoleyn Treated by Electrolysis and Respirometric Method. J Waste Water Treatment Analysis 1:101. doi:10.4172/21577587.1000101

Page 2 of 5

present in it was used to prepare a simulated wastewater focusing in 1,2-dihydro-2,2,4-trimethylquinoleyn, which is an aromatic amine with trade name Naugard $Q^{\circledR}$.

Moreover, a very good model to predict the real effluent treatment is simulation a wastewater with related concentration of the compound analyzed. Therefore, it was done a comparison between real effluent and simulated wastewater containing Naugard $Q^{\circledR}$.

\section{Simulated wastewater}

The simulated wastewater was prepared at laboratory using Naugard $Q^{\circledR}$ solution. This compound is sold for to act as polymerization precursor and in the experimental runs was used without any further purification. Furthermore, Naugard $Q^{\circledR}$ has tablet form and for this reason it was ground using a porcelain mortar and pestle.

Hence, $1.00 \mathrm{~g}$ of compound after ground it was dissolved in $5.0 \mathrm{~mL}$ of ethyl alcohol (Merck P.A.) and the volume was completed to 1,000 $\mathrm{mL}$ with deionized water (Millipore ${ }^{\circledR}$ Milli-Q system). As a supporting electrolyte it was used sodium sulphate $0.15 \mathrm{M}$ (Merck PA).

At the same way of the real effluent, the solution was filtered and stored in low temperature and without light incidence. Naugard $Q^{\circledR}$ concentration in the simulated wastewater was $134.06 \mathrm{mg} \mathrm{L}^{-1}$.

\section{Apparatus}

The batch experiments were conducted in a $250 \mathrm{~mL}$ reactor, i.e., an electrolytic cell as described in previous work by Inazaki et al. [11]. A DC power supply (Dawer, FCC-3005D) with current-voltage controls and displays was employed to provide the electric power and a magnetic stirrer was used during electrolysis experiments. The DSA electrodes (area $=60.16 \mathrm{~cm}^{2}$ ) were prepared as according to an expired patent [12], and then have been placed vertically apart $3 \mathrm{~mm}$ in the electrolytic cell. The system was operated at constant current density (J) of $25.0 \mathrm{~mA} \mathrm{~cm}{ }^{-2}$ with electrolysis duration of $5,15,30,45$ and $60 \mathrm{~min}$.

Analyses: Spectrophotometer Shimadzu ${ }^{\circledR}$ model 2401 PC was used to provide rapid indication of alteration and degradation of the Naugard $Q^{\circledR}$ compound. Gas chromatography was performed by using a model HPI 5890 series 2, stationary phase $100 \%$ dymethylpolythilozane, volume sample of 0.5 to $1.0 \mu \mathrm{L}$, column length of $30 \mathrm{~m}$, column internal diameter of $0.53 \mathrm{~mm}$, film thickness of $0.88 \mu$, injector temperature of $250^{\circ} \mathrm{C}$, detector temperature of $350^{\circ} \mathrm{C}$, not polar column, detector flame ionization and a flow of Helium gas.

\section{Biodegradation experiment}

Soil source: The soil samples for the laboratory experiments were collected from a site located in the city of Rio Claro (Sao Paulo, Brazil) and thereafter the soil was dried at room temperature, sifted in sieve of mesh $0.2 \mathrm{~mm}$ and stored in polyethylene flask. The soil was classified as sandy, sandy fine sub-class by Instituto Campineiro de Análise de Solo e Adubo de Campinas, Brazil. The soil had 30\% thick sand, $55.5 \%$ fine sand, $12.3 \%$ silt and $2.2 \%$ clay, and $\mathrm{pH} 5.0$ in water.

Since the microbial respiration rate is correlated with the level moisture content of the soil [13-15], in this work the soil moisture was kept at $60 \%$ of the soil's moisture-holding capacity.

Bacterial source: The degrading microorganisms used in respirometric test were collected from the soil of the chemical industry and from the wastewater treatment plant. In laboratory, that material containing the microorganisms has been exposed to Naugard $\mathrm{Q}^{\circledR}$ compound to obtain a better adaptation. The microorganisms were acclimated to grow on a test medium by using the Naugard $Q^{\circledR}$ compound as unique carbon source. The test medium was described by Aaronson [16] and the following alterations were made: $1.00 \mathrm{~g}$ of $\mathrm{K}_{2} \mathrm{HPO}_{4} ; 0.20 \mathrm{~g}$ of $\mathrm{MgSO}_{4} .7 \mathrm{H}_{2} \mathrm{O} ; 0.10 \mathrm{~g}$ of NaCl$; 0.10 \mathrm{~g}$ of $\mathrm{CaCl}_{2} ; 0.02 \mathrm{~g}$ of $\mathrm{FeCl}_{2} ; 1.00 \mathrm{~g}$ of $\left(\mathrm{NH}_{4}\right)_{2} \mathrm{SO}_{4} ; 1000 \mathrm{~mL}$ of $\mathrm{H}_{2} \mathrm{O} ; 0.60 \mathrm{~g}$ of Naugard $\mathrm{Q}^{\circledR}$ compound; $\mathrm{pH}$ of 7.2 to 7.5 .

Afterward, nutrient agar plate-counting technique was used for obtaining the degrading microorganisms by using Plate Count Agar medium (PCA, Difco ${ }^{\circledR}$ Laboratories). The microorganisms obtained were resuspended in liquid PCA medium, and it was standardized with absorbance about 0.40 a.u. at $\lambda=540 \mathrm{~nm}$, consisting in the inoculum for the biological treatment.

Biodegradation conditions: During the respirometric test, carbon dioxide evolution rates were monitored by using respirometric flasks according to Bartha and Pramer's respirometry [17]. Carbon dioxide which was evolved during the microbial respiration process was trapped in $10.0 \mathrm{~mL}$ of aqueous solution of $\mathrm{KOH} 0.20 \mathrm{M}$ located in the side arm attached to the Bartha respirometric flask. After $1.0 \mathrm{~mL}$ of $\mathrm{BaCl}_{2} 0.05 \mathrm{M}$ was added to $\mathrm{KOH}$ solution in order to precipitate the carbonate ions, the amount of carbon dioxide was then measured by titration of the residual $\mathrm{KOH}$ with a standard solution of $\mathrm{HCl}$ $0.10 \mathrm{M}$. The calculations of $\mathrm{CO}_{2}$ evolution, biodegraded carbon and biodegradation effectiveness were accomplished in agreement with Technical Standard L6.350 [18].

For the simulated wastewater, each Bartha respirometric flask contained $50.0 \mathrm{~g}$ of soil, $1.50 \mathrm{~mL}$ of inoculum with microorganisms previously acclimated to Naugard $\mathrm{Q}^{\circledR}$ compound and $5.00 \mathrm{~mL}$ of simulated wastewater containing Naugard $Q^{\circledR}$, which was treated during 5, 30 and $60 \mathrm{~min}$ by electrolysis. Two blank controls were maintained: only soil (S) and inoculum added to the soil (IS).

Biodegradation was also evaluated for the real effluent. Four systems were done according to different times of electrolytic treatment: 0 minutes (control), 10 minutes, 25 minutes and 50 minutes. Each respirometric flask was composed by $100 \mathrm{~mL}$ of the effluent and $1.00 \mathrm{~mL}$ of microorganisms' inoculum. The respirometry assays were done in duplicates for all samples and incubated at $28^{\circ} \mathrm{C}$.

\section{Results and Discussion}

\section{Electrolytic treatment}

Simulated wastewater: Analysis of the simulated wastewater after the electrolytic treatment showed that $\mathrm{pH}$ values gradually decreased from 5.7 to 3.8 along electrolysis time increase, probably due to solvent breakdown and alterations on Naugard $Q^{\circledR}$ compound molecular structure, resulting in $\mathrm{H}^{+}$production. Conductivity has increased slightly from 17.4 to $19.3 \mathrm{mS} \mathrm{cm}^{-1}$ with the increasing of electrolysis time, evidencing that there was small increment in total ionic concentration during the treatment.

\begin{tabular}{|l|l|l|}
\hline $\begin{array}{l}\text { Electrolysis time } \\
(\mathrm{min})\end{array}$ & $\begin{array}{l}\text { Absorbance at } \\
230 \mathrm{~nm}\end{array}$ & Naugard ${ }^{\circledR}$ concentration $\left(\mathrm{mg} \mathrm{L}^{-1}\right)$ \\
\hline 0 & 2.2994 & 134.06 \\
\hline 5 & 1.9801 & 115.53 \\
\hline 15 & 1.7125 & 100.00 \\
\hline 30 & 1.4793 & 86.46 \\
\hline 45 & 1.2537 & 73.37 \\
\hline 60 & 1.1028 & 64.61 \\
\hline
\end{tabular}

Table 1: Naugard $Q^{\circledR}$ concentration according to UV-Vis absorbance for simulated wastewater (Abs $=-0,01048+0,01723$. [Naugard $Q^{\circledR}$ ]; $\left.R^{2}=0,99334\right)$. 
Citation: Inazaki TH, de Moraes PB, Regis G, Matos Lopes PR, Montagnolli RN, et al. (2010) Wastewater Containing 1,2-Dihydro-2,2,4Trimethylquinoleyn Treated by Electrolysis and Respirometric Method. J Waste Water Treatment Analysis 1:101. doi:10.4172/21577587.1000101

Detection at the maximum wavelength was used to follow the dependence of the concentration reduction on time. Table 1 shows concentration reduction from $134.06 \mathrm{mg} \mathrm{L}^{-1}$ to $64.61 \mathrm{mg} \mathrm{L}^{-1}$, i.e., concentration reduction by $52.04 \%$ in 60 min of electrolysis (Table 1 ).

UV-visible spectra of simulated wastewater had been acquired in each electrolysis time to establish their maximum absorbance wavelength (Figure 1). After electrolytic treatment, the peaks on the spectra were shifted to higher wavelengths and there was reduction in the absorption intensity. The untreated wastewater presented maximum absorbance at $229.5 \mathrm{~nm}$. After $60 \mathrm{~min}$ of electrolysis the peak was shifted to $234.5 \mathrm{~nm}$.

Therefore, it is possible to conclude that with the increasing of electrolysis time the substances present on the Naugard $Q^{\circledR}$ tablet showed a greater chemical transformation. According to Régis and Bidoia [1], the electrolytic process allows modification in aromatic chemicals most probably by opening the aromatic ring.

In (Figure 2) is shown a chromatogram of the untreated wastewater containing the Naugard $\mathrm{Q}^{\circledR}$ compound. Here, there are five peaks with following retention times: 9.108, 10.051, 10.310, 10.897 and $18.835 \mathrm{~min}$. The peak with larger area (71\%), whose

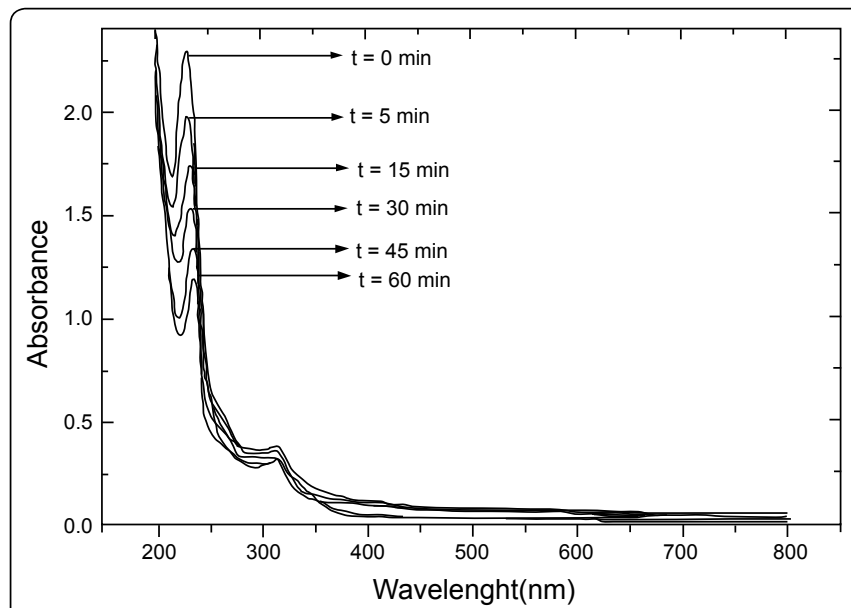

Figure 1: UV-visible spectra of simulated wastewater during electrolysis. $\mathrm{J}=$ $25.0 \mathrm{~mA} \mathrm{~cm}^{-2}, 25^{\circ} \mathrm{C}$.

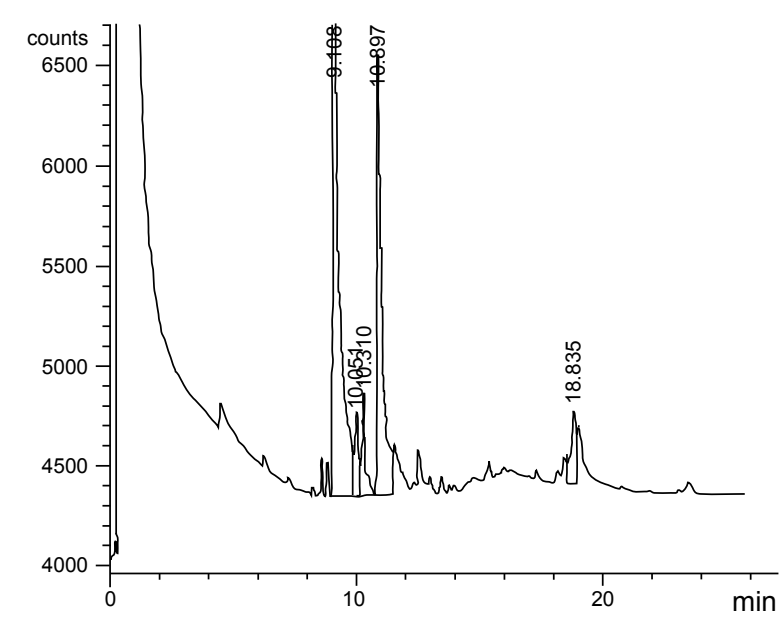

Figure 2: Gas chromatogram of the untreated wastewater.

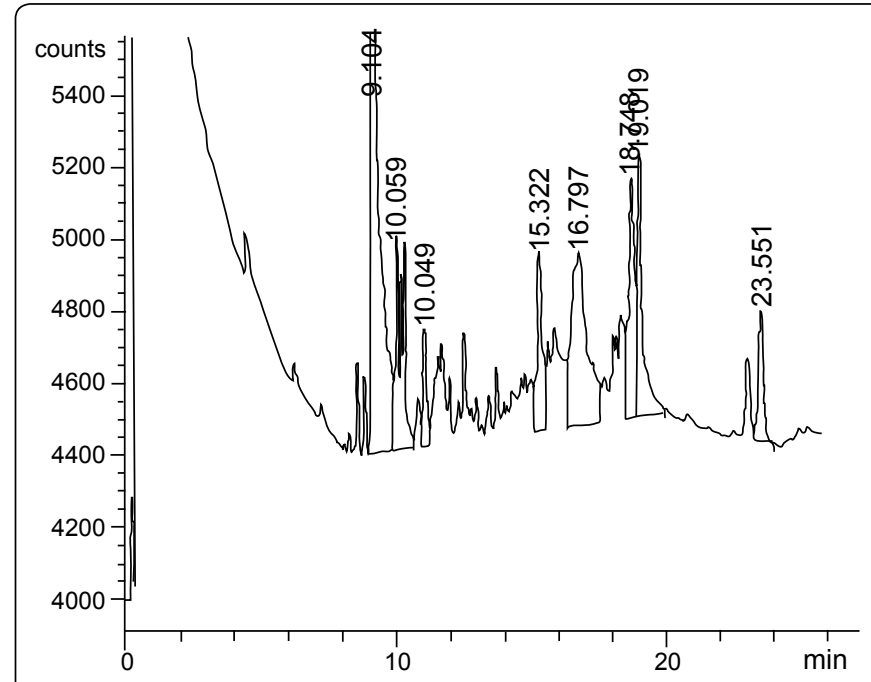

Figure 3: Gas chromatogram of the simulated wastewater in $30 \mathrm{~min}$ of electrolysis $\left(\mathrm{J}=25.0 \mathrm{~mA} \mathrm{~cm}^{-2}, 25^{\circ} \mathrm{C}\right)$.

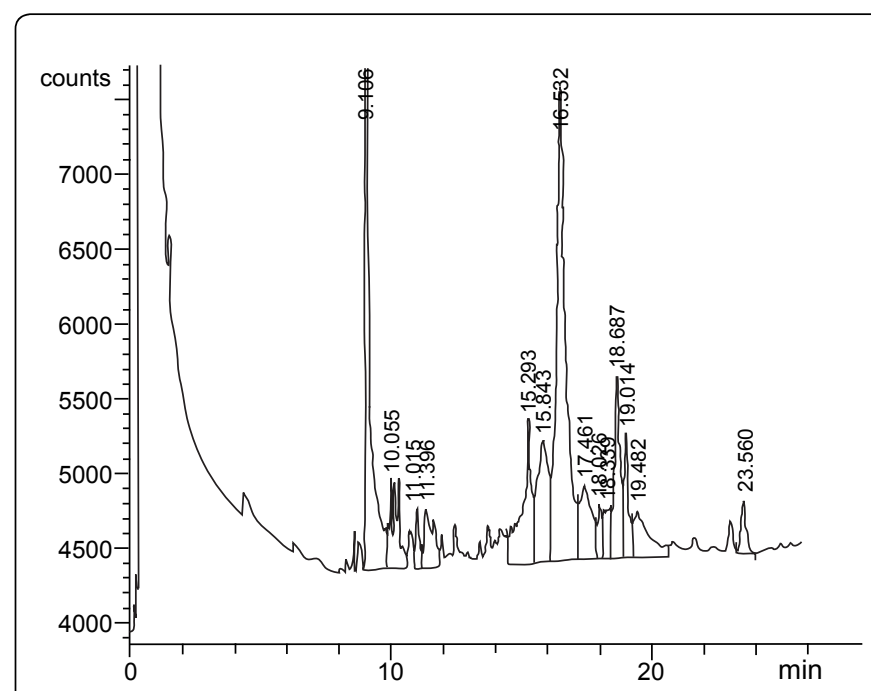

Figure 4: Gas chromatogram of the simulated wastewater in $60 \mathrm{~min}$ of electrolysis $\left(\mathrm{J}=25.0 \mathrm{~mA} \mathrm{~cm}^{-2}, 25^{\circ} \mathrm{C}\right)$.

retention time is $9.108 \mathrm{~min}$, probably corresponds to the Naugard $\mathrm{Q}^{\circledR}$ compound. The other peaks in gas chromatogram correspond to impurities present in compound tablet, since the same was used without any further purification. (Figure 3) demonstrates a gas chromatogram obtained from the wastewater treated during $30 \mathrm{~min}$ of electrolysis. The number of peaks is higher than gas chromatogram of untreated wastewater. Probably after $30 \mathrm{~min}$ of electrolysis, the initial compounds presented in Naugard $Q^{\circledR}$ tablet originated new byproducts, which were more biodegradable or biocompatible for microbial consortium in respirometric test.

A gas chromatogram obtained from the wastewater treated during $60 \mathrm{~min}$ by electrolytic treatment was presented in (Figure 4). There are several peaks with different retention times from that ones present in the gas chromatogram of untreated wastewater and wastewater treated during $30 \mathrm{~min}$ of electrolysis. That result suggests that $60 \mathrm{~min}$ of electrooxidation induced new molecules formation in solution. Still, those new molecules were less biodegradable than initial compounds present in untreated wastewater, since the new 
Citation: Inazaki TH, de Moraes PB, Regis G, Matos Lopes PR, Montagnolli RN, et al. (2010) Wastewater Containing 1,2-Dihydro-2,2,4Trimethylquinoleyn Treated by Electrolysis and Respirometric Method. J Waste Water Treatment Analysis 1:101. doi:10.4172/21577587.1000101

molecules showed low biodegradation effectiveness by microbial consortium during respirometric test.

Real effluent: Real effluent pH changed from 5.62 to 6.41 after 50 minutes electrolytic treatment. It was observed that $\mathrm{pH}$ values gradually decreased along electrolysis time increase, due to solvent breakdown and alterations on Naugard $Q^{\circledR}$ compound molecular structure, resulting in $\mathrm{H}^{+}$production. Also, real effluent conductivity reached higher values after prolonged electrolytic treatment time. Conductivity in real effluent has increased slightly by $6.07 \mathrm{mS} \mathrm{cm}$ after 30 minutes with the increasing of electrolysis time, evidencing that there was small increment in total ionic concentration during the treatment.

During both real effluent and simulated wastewater electrolytic treatment analysis, a slight temperature increase by $3.6^{\circ} \mathrm{C}$ was observed. This occurred due to fluid electrical resistance during electrolysis, however such heating did not cause changes in effluent chemical properties nor affected microorganisms viability.

UV-visible absorbance was determined after 10, 20, 30 and 40 minutes of real effluent electrolytic treatment using different electrodes. After 20 minutes, it was noticeable a decrease in various substances concentration originally present in real effluent, including Naugard $Q^{\circledR}$. As seen in (Figure 5), an analysis onto peak heights in spectra from different time periods treatments confirmed such fact, and also demonstrated changes in Naugard $Q^{\circledR}$ maximum absorbance wavelength.

According to (Figure 5), the absorbance values at $230 \mathrm{~nm}$ were determined as Naugard $Q^{\circledR}$ concentration for different times of electrolytic treatment for real effluent (Table 2).

\section{Biodegradation}

Simulated wastewater: A microbial consortium had been

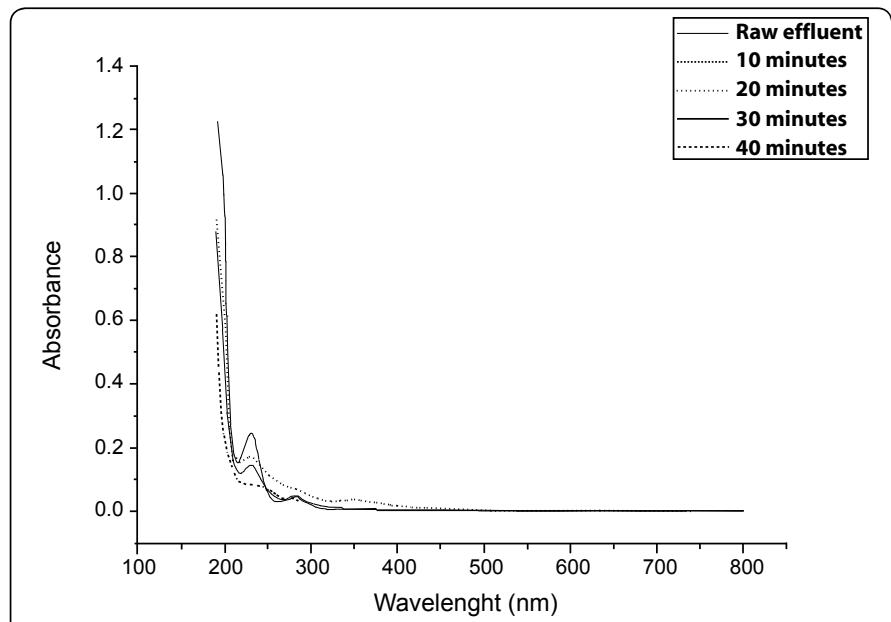

Figure 5: UV-visible spectra of real effluent during electrolysis. $\mathrm{J}=25.0 \mathrm{~mA}$ $\mathrm{cm}^{-2}, 25^{\circ} \mathrm{C}$.

\begin{tabular}{|l|l|l|}
\hline $\begin{array}{l}\text { Electrolysis time } \\
(\mathrm{min})\end{array}$ & $\begin{array}{l}\text { Absorbance at } \\
230 \mathrm{~nm}\end{array}$ & Naugard $\mathrm{Q}^{\circledR}$ concentration $\left(\mathrm{mg} \mathrm{L}^{-1}\right)$ \\
\hline 0 & 0.2468 & 14.93 \\
\hline 10 & 0.1741 & 10.71 \\
\hline 20 & 0.1714 & 10.56 \\
\hline 30 & 0.1459 & 9.08 \\
\hline 40 & 0.0856 & 5.58 \\
\hline
\end{tabular}

Table 2: Naugard $Q^{\circledR}$ concentration according to UV-Vis absorbance for real effluent (Abs $=-0,01048+0,01723$. [Naugard $Q^{\circledR}$ ]; $\left.R^{2}=0,99334\right)$.

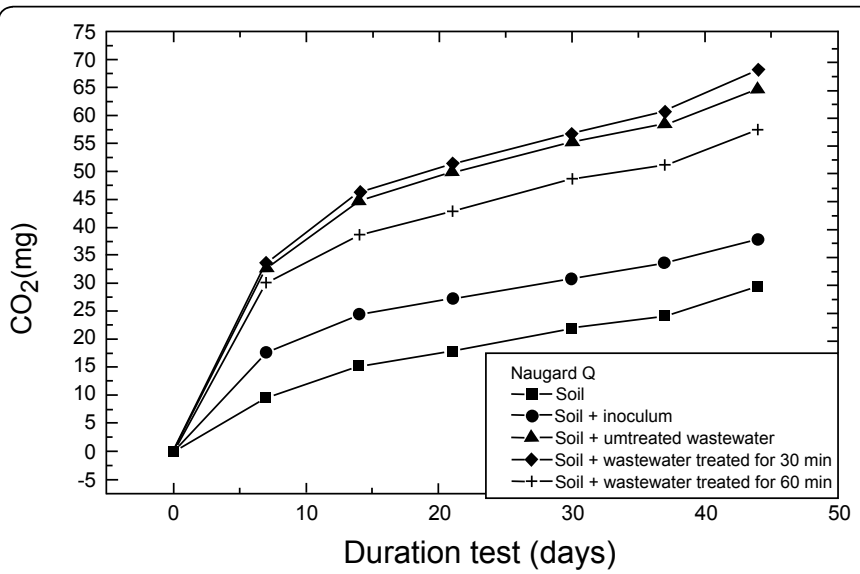

Figure 6: Accumulated $\mathrm{CO}_{2}$ from biodegradation of the simulated wastewater using Bartha and Pramer's respirometric method.

used to degrade the Naugard $Q^{\circledR}$ compound present in untreated wastewater and the one treated by the electrochemical process. The biodegradation experiments in soil were performed by using Bartha and Pramer's respirometric method [17-18]. In (Figure 6) is shown the accumulated evolution of $\mathrm{CO}_{2}$ results from biodegradation of simulated wastewater containing Naugard $\mathrm{Q}^{\circledR}$ compound.

During first week of experiment the largest rates of $\mathrm{CO}_{2}$ evolution were found:1.37 $\mathrm{mgCO}_{2}$ day $^{-1}$ (soil), $2.51 \mathrm{mgCO}_{2}$ day $^{-1}$ (soil and inoculum), $4.68 \mathrm{mgCO}_{2}$ day $^{-1}$ (soil, inoculum and untreated wastewater), $4.79 \mathrm{mgCO}_{2}$ day $^{-1}$ (soil, inoculum and wastewater treated for $30 \mathrm{~min}$ ) and $4.30 \mathrm{mgCO}_{2}$ day $^{-1}$ (soil, inoculum and wastewater treated for $60 \mathrm{~min}$ ). During the remaining days, the $\mathrm{CO}_{2}$ evolution decreased and the following rates have been obtained: $0.55 \mathrm{mgCO}_{2}$ day $^{-1}$ (soil), $0.56 \mathrm{mgCO}_{2}$ day $^{-1}$ (soil and inoculum), $0.87 \mathrm{mgCO}_{2}$ day $^{-1}$ (soil, inoculum and untreated wastewater), $0.95 \mathrm{mgCO}_{2}$ day $^{-1}$ (soil, inoculum and wastewater treated for $30 \mathrm{~min}$ ) and $0.74 \mathrm{mgCO}_{2}$ day $^{-1}$ (soil, inoculum and wastewater treated for $60 \mathrm{~min}$ ).

All samples of simulated wastewater disposed in soil containing the inoculum showed $\mathrm{CO}_{2}$ evolution by microbial consortium. In opposition, Bartha respirometric flasks containing the simulated wastewater treated during $30 \mathrm{~min}$ of electrolysis showed more $\mathrm{CO}_{2}$ evolution than other treated samples. After $30 \mathrm{~min}$ of electrochemical treatment the simulated wastewater became more biocompatible to microorganisms due to the alteration of the initial compounds present in Naugard $Q^{\circledR}$ tablet. Also, the formation of more biodegradable byproducts in the solution was observed as well.

The electrolysis time plays an important role in byproducts formation, seeing as in $30 \mathrm{~min}$ of electrolysis there were less oxidized products compared to $60 \mathrm{~min}$. Thus, the wastewater treated by electrolysis above $30 \mathrm{~min}$ presented byproducts that were more difficult to degrade by microorganisms in respirometric test.

Furthermore, it was observed that there was not an initial lag phase by microbial consortium probably because microorganisms were previously acclimated to the Naugard $Q^{\circledR}$ compound. All samples showed higher $\mathrm{CO}_{2}$ evolution rates at $7^{\text {th }}$ day of experiment followed by a decreasing of $\mathrm{CO}_{2}$ evolution. It suggests that the microorganisms degraded more biodegradable substances and then the persistent compounds remained. These persistent compounds were slowly degraded towards the end of experiment.

Real effluent: Real effluent biodegradation processes can successfully be evaluated by $\mathrm{CO}_{2}$ quantification, in either raw or 
Citation: Inazaki TH, de Moraes PB, Regis G, Matos Lopes PR, Montagnolli RN, et al. (2010) Wastewater Containing 1,2-Dihydro-2,2,4Trimethylquinoleyn Treated by Electrolysis and Respirometric Method. J Waste Water Treatment Analysis 1:101. doi:10.4172/21577587.1000101

Page 5 of 5

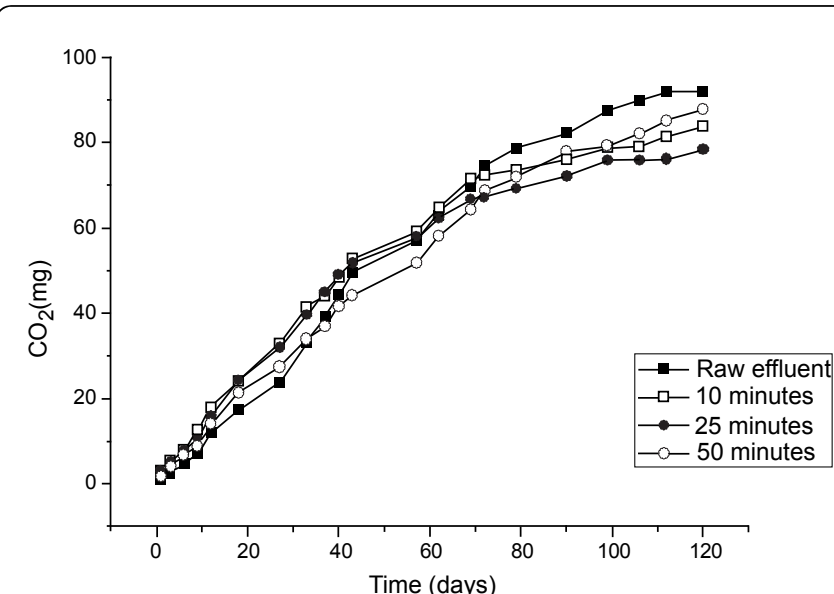

Figure 7: Accumulated $\mathrm{CO}_{2}$ from biodegradation of the real effluent using Bartha and Pramer's respirometric method.

electrolyzed samples by respirometric methods (Figure 7). During the 20 first biodegradation days, electrolyzed effluents had a higher $\mathrm{CO}_{2}$ production compared to raw effluent sample. A better biodegradation performance was observed in assays containing electrolyzed effluents. Amongst electrolyzed effluents, the most biodegraded were the ones that underwent 10 minutes $\left(24.2 \mathrm{mgCO}_{2}\right)$ and 25 minutes $(24.5 \mathrm{mgCO})$ treatment. $\mathrm{CO}_{2}$ production in raw effluent surpassed electrolyzed effluent after 25 days.

Biodegradation occurred on every assay, including control assays due to favorable conditions to microorganisms' growth. Thus, all electrolytic treatments showed $\mathrm{CO}_{2}$ production. Also, the 10 minute treated sample accumulated more $\mathrm{CO}_{2}$ after 70 days of biodegradation (71.5 $\left.\mathrm{mgCO}_{2}\right)$, meaning a faster biodegradation response. However, after the $70^{\text {th }}$ day, control assays accumulated more $\mathrm{CO}_{2}\left(83.9 \mathrm{mgCO}_{2}\right)$.

Regarding biodegradation within electrolyzed effluents, the 25 minutes sample presented a $\mathrm{CO}_{2}$ accumulation much similar to the 10 minutes sample up to $62^{\text {nd }}$ day, producing 59.2 and 57.8 respectively. Moreover, the 50 minutes has a less efficient biodegradation during the first 80 days, but exceeded the other ones after that, increasing from $71.9 \mathrm{mgCO}_{2}$ to $87.8 \mathrm{mgCO}_{2}$.

A minor biodegradation occurred during the first 40 days in control assay when compared to electrolyzed effluents. Still, after 70 days, this was the assay which presented the highest $\mathrm{CO}_{2}$ accumulation, reaching values of $92.1 \mathrm{mgCO}_{2}$ produced.

As for the electrolyzed effluents, the fastest $\mathrm{CO}_{2}$ production was in 10 minutes treatment sample. Electrolytic treatments transform persistent substances into more biodegradable ones. This is favorable to microorganisms' metabolism, which makes them able to perform an increased assimilation and ease during biodegradation processes. This treatment leads to an accelerated biodegradation by lowering adaptation and latency periods. Hence electrolytic treatments are improvement to real effluents biodegradation.

\section{Conclusions}

Naugard $Q^{\circledR}$ concentration decreased after electrolytic treatments in both simulated wastewater and real effluent. Electrolytic treatment of simulated wastewater containing 1,2-dihydro-2,2,4trimethylquinoleyn (Naugard $\mathrm{Q}^{\circledR}$ ) using DSA electrodes at $25.0 \mathrm{~mA}$ $\mathrm{cm}^{-2}$ during 60 min reduced concentration of Naugard $Q^{\circledR}$ by $52.04 \%$, whereas after 40 minutes real effluent Naugard $Q^{\circledR}$ concentration was more reduced, as a $62.6 \%$ reduction was observed. UV- visible spectrophotometry and gas chromatography demonstrated significant alterations in the molecular structure of the compound Naugard $Q^{\circledR}$. After $30 \mathrm{~min}$ of electrolysis, byproducts have been produced and they were more biocompatible to microorganisms. However, the simulated wastewater treated for $60 \mathrm{~min}$ of electrolysis presented lower biodegradation effectiveness than other samples of treated wastewater. Probably, after $60 \mathrm{~min}$ of electrochemical treatment the initial compounds present in the Naugard $Q$ tablet were transformed in new and more persistent substances. It is possible to conclude that $30 \mathrm{~min}$ of electrolysis is enough to improve simulated wastewater biodegradability. Furthermore, real effluents biodegradation response was equally faster in assays that underwent 10 and 25 minutes of electrolytic treatment, as they initially produced more $\mathrm{CO}_{2}$. Therefore, the electrochemical treatment followed by bioremediation is an efficient treatment for an effluent from a rubber antioxidant and antiozonant chemical industry containing the Naugard $Q^{\circledR}$ compound.

\section{Acknowledgements}

The authors thank FAPESP, CAPES and CNPq for financial support.

\section{References}

1. Régis G, Bidoia ED (2001) Electrolytic treatment of an effluent of a chemica industry for monitoring toxicity by Saccharomyces cerevisiae. Salusvita 20:53-60.

2. Chung K, Kircovsky L, Kirkov A, Purcell WP (1997) Review of mutagenicity of monocyclic aromatic amines: quantitative structure-activity relationships. Mutat Res 387:1-16.

3. Benigni R, Passerini L (2002) Carcinogenicity of the aromatic amines: from structure-activity relationships to mechanisms of action and risk assessment Mutat Res 511:191-206

4. Saracco G, Solarino L, Specchia V, Maja M (2001) Electrolytic abatement of biorefractory organics by combining bulk and electrode oxidation processes. Chem Eng Sci 56:1571-1578.

5. Azzam MO, Al-Tarazi M, Tahboub Y (2000) Anodic destruction of 4-chloropheno solution. J Hazard Mater B 75:99-113.

6. Polcaro AM, Palmas S, Renoldi F, Mascia M (2000) Three-dimensional electrodes for the electrochemical combustion of organic pollutants. Electrochim Acta 46:389-394.

7. Sakakibara Y, Nakayama T (2001) A novel multi-electrode system for electrolytic and biological water treatments: electric charge transfer and application to denitrification. Water Res 35:768-778.

8. Feng YJ, Li XY (2003) Electro-catalytic oxidation of phenol on several metal-oxide electrodes in aqueous solution. Water Res 37:2399-2407.

9. Israilides CJ, Vlyssides AG, Mourafeti VN, Karvouni G (1997) Olive oil wastewate treatment with the use of an electrolysis system. Bioresour Technol 61:163-170.

10. Moraes PB, Bertazzoli R (2005) Electro-degradation of landfill leachate in a flow electrochemical reactor. Chemosphere 58:41-46.

11. Inazaki TH, Pião ACS, Bidoia ED (2002) Treatment of wastewater containing the compound n-phenil-n'-1,3-dimethylbutyl-p-phenylenediamine using system of electrolysis. Arq Inst Biol 69:150-152.

12. De Nora V (1970) British Patent 1, 231, 280;1,235,570.

13. Campbell R (1977) Microbial Ecology. Blackwell, New York, USA.

14. Mitchell R (1992) Environmental Microbiology. Wiley-Liss, New York, USA

15. Balba MT, Al-Awadhi N, Al-Daher R (1998) Bioremediation of oil-contaminated soil: microbiological methods for feasibility assessment and field evaluation. J Microbiol Meth 32:155-164.

16. Azzam MO, Al-Tarazi M, Tahboub Y (2000) Anodic destruction of 4-chlorophenol solution. J Hazard Mater B 75:99-113.

17. Bartha R, Pramer D (1965) Features of a flask and method for measuring the persistence and biological effects of pesticides in soil. Soil Sci 100:68-70.

18. Cetesb (1990) Soils: determination of residues biodegradation-Bartha's respirometric method. Technical Norm L6.350. Sao Paulo, Brazil. 